\section{Effects of Electrical Conductivity of Hydroponic Nutrient Solution on Leaf Gas Exchange of Five Greenhouse Tomato Cultivars}

\author{
Min $\mathrm{Wu}^{1}$ and Chieri Kubota ${ }^{1,2}$
}

ADDITIONAL INDEX wORDs. Lycopersicon esculentum, Solanum lycopersicum, fruit quality, photosynthesis, reproductive stage, stomatal conductance, total soluble solids, transpiration, vegetative stage

Summary. Five cultivars (Blitz, Mariachi, Quest, Rapsodie, and Trust) of tomato (Solanum lycopersicum) were grown hydroponically in a greenhouse to determine photosynthetic and transpirational responses to three electrical conductivities (EC) [2.3 (control), 4.8 , and $8.4 \mathrm{dS} \cdot \mathrm{m}^{-1}$ ] of inflow nutrient solution. Leaf photosynthetic light response curves were measured during the early vegetative growth stage for cv Mariachi and Rapsodie and during the reproductive growth stage for all five cultivars. Leaf transpiration rate and leaf conductance were measured for all five cultivars in both stages. During the vegetative growth stage, high EC treatment of 8.4/14.3 dS $\mathrm{m}^{-1}$ inflow/efflux solution reduced leaf conductance and transpiration rate by $28 \%$ and $29 \%$, respectively, compared with low EC treatment $\left(2.3 / 5.9 \mathrm{dS} \cdot \mathrm{m}^{-1}\right)$, regardless of cultivar. Effects of EC treatments on leaf photosynthetic light response curves were cultivar specific. For 'Mariachi', moderate EC $\left(4.8 / 8.7 \mathrm{dS} \cdot \mathrm{m}^{-1}\right)$ and high EC treatments in the vegetative growth stage reduced the maximum photosynthetic rate by $49 \%$ compared with the low EC treatment. However, for 'Rapsodie', the moderate EC treatment increased the maximum photosynthetic rate during the vegetative stage by $8 \%$ and $47 \%$ compared with low and high EC treatments, respectively. During reproductive growth stage, EC treatment did not significantly affect the transpiration rate, but high EC treatment reduced the leaf conductance by $15 \%$, regardless of cultivar. Parameters of leaf photosynthetic response curves were affected by cultivar and EC treatment. Compared with the low EC treatment, the moderate EC treatment did not significantly affect the maximum photosynthetic rate of any cultivar except 'Rapsodie', which showed the greatest maximum photosynthetic rate in the moderate EC treatment. The results showed that the plant physiological response under elevated EC was cultivar and growth-stage specific, and increasing the inflow EC to the moderate level of around $4.8 \mathrm{dS} \cdot \mathrm{m}^{-1}$ during the reproductive growth stage would not negatively impact photosynthesis, transpiration, and leaf conductance of tomato plants, for all cultivars tested in the present experiment.

$\mathrm{T}$ Tomato has been an important horticultural crop in the U.S. market (Jones, 1999; Rick, $1995)$. For fresh tomato production, 159,664 and $1,594,241$ tons of tomatoes were produced in the greenhouse and field, respectively, in the United States in 2003 (Cook and Calvin, 2005). Since 1985, the consumption of fresh tomatoes in the United States increased about $30 \%$, with an annual per capita consumption level estimated at $8.8 \mathrm{~kg}$ in 2003 (Cook and Calvin, 2005). The percentage of greenhouse tomatoes available in the U.S. retail markets has increased

CEAC Paper No. D-125929-10-06. This paper includes results funded by the Controlled Environment Agriculture Program at the University of Arizona.

${ }^{1}$ Department of Plant Sciences, University of Arizona, Tucson, AZ 85721

${ }^{2}$ Corresponding author. E-mail: ckubota@ag.arizona. edu. dramatically during the past decade and accounts for $37 \%$ of the weekly quantity of tomatoes sold in the average U.S. supermarket in 2003 (Cook and Calvin, 2005). In Mexico, the total area of greenhouse used for production of vegetables is increasing rapidly, reportedly as high as 30\% annually (Steta, 2004), and growers are now shifting toward production of higher quality tomato fruit to obtain premium price. One such shift is pursuing better tomato fruit flavor similar to what consumers perceive as 'home garden' flavor, and another shift is a reduced use of pesticides to produce a safer fruit.

Sugar and organic acids are the major components of tomato flavor (Stevens et al., 1977). Total soluble solid concentration [TSS; percent $(\mathrm{w} / \mathrm{v})$ at $\left.20^{\circ} \mathrm{C}\right]$ is the most common index for overall flavor of tomato fruit associated directly with sugar and organic acid concentrations in tomato juice (Stevens et al., 1977; Young et al., 1993). In hydroponic tomato production, increasing electrical conductivity (EC) of nutrient solution is a well-known technique to increase TSS of tomato fruit because the decreased osmotic potential $\left(\psi_{\mathrm{S}}\right)$ of nutrient solution restricts the water transport to fruit, resulting in higher concentrations of soluble solids (Adams, 1991; Cornish, 1992; Dorais et al., 2001; Lin and Glass, 1999; Mitchell et al., 1991). EC can be increased by increasing overall strength (total concentration) of the nutrient solution or by adding sodium chloride $(\mathrm{NaCl})$. The former method can be achieved by altering dilution rate of injectors for the stock solutions, but the latter is more widely accepted by commercial growers as being economically feasible.

One of the disadvantages of increasing TSS by high EC treatment is a reduction in fruit size by reducing water content in fresh fruit (Adams and Ho, 1989). The EC of nutrient solution used for commercial hydroponic tomato production generally ranges between 1.6 and $5.0 \mathrm{dS} \cdot \mathrm{m}^{-1}$. Dorais et al. (2001) examined the effects of EC on tomato fruit yield and found that tomato yield was not reduced when EC ranged from 2.1 to $5.1 \mathrm{dS} \cdot \mathrm{m}^{-1}$. Adams (1991) reported that, compared with the control

\begin{tabular}{llll}
\hline $\begin{array}{l}\text { Units } \\
\text { To convert U.S. to SI, } \\
\text { multiply by }\end{array}$ & U.S. unit & SI unit & $\begin{array}{l}\text { To convert SI to U.S., } \\
\text { multiply by }\end{array}$ \\
\hline 29.5735 & $\mathrm{fl} \mathrm{oz}$ & $\mathrm{mL}$ & 0.0338 \\
0.3048 & $\mathrm{ft}$ & $\mathrm{m}$ & 3.2808 \\
2.54 & inch(es) & $\mathrm{cm}$ & 0.3937 \\
0.4536 & $\mathrm{lb}$ & $\mathrm{kg}$ & 2.2046 \\
1 & $\mathrm{mmho} / \mathrm{cm}$ & $\mathrm{dS} \cdot \mathrm{m}^{-1}$ & 1 \\
1 & $\mathrm{ppm}$ & $\mathrm{mg} \cdot \mathrm{L}^{-1}$ & 1 \\
0.9072 & ton $(\mathrm{s})$ & $\mathrm{Mg}$ & 1.1023 \\
$\left({ }^{\circ} \mathrm{F}-32\right) \div 1.8$ & ${ }^{\circ} \mathrm{F}$ & ${ }^{\circ} \mathrm{C}$ & $\left(1.8 \times{ }^{\circ} \mathrm{C}\right)+32$ \\
& & & \\
\end{tabular}


treatment of $3.0 \mathrm{dS} \cdot \mathrm{m}^{-1} \mathrm{EC}$, application of $8 \mathrm{dS} \cdot \mathrm{m}^{-1} \mathrm{EC}$ decreased tomato yield by $4 \%$ to $5 \%$ per $\mathrm{dS} \cdot \mathrm{m}^{-1}$, whereas $12 \mathrm{dS} \cdot \mathrm{m}^{-1} \mathrm{EC}$ decreased tomato yield by $6 \%$ to $8 \%$ per $\mathrm{dS} \cdot \mathrm{m}^{-1}$, where both high EC treatments were achieved by adding $\mathrm{NaCl}$ to the nutrient solution. Another report showed that there was no significant difference in yield between plants grown under 2.7 and $4.5 \mathrm{dS} \cdot \mathrm{m}^{-1}$; however, the yield was reduced linearly when the EC was increased from 4.5 to $6.0,7.4$, or $8.6 \mathrm{dS} \cdot \mathrm{m}^{-1}$ (Leonardi et al., 2004). These results suggest that when EC was increased moderately to around 5 $\mathrm{dS} \cdot \mathrm{m}^{-1}$, TSS of fruit could be enhanced without yield reduction.

Under high EC, the tomato plant may be affected by water stress from the low water potential of the nutrient solution, which is caused by the decreased (or more negative) $\psi_{\mathrm{S}}$ of the solution, or affected by excessive ion uptake because of greater ion concentrations in solution (Greenway and Munns, 1980). Photosynthesis, transpiration, and stomatal conductance $\left(g_{\mathrm{s}}\right)$ under high EC were affected by limited irrigation or increased salt concentrations in nutrient solution (Romero-Aranda et al., 2001). These physiological parameters are closely related to plant growth, as well as to fruit yield and quality. Xu et al. (1995) studied the effects of EC of hydroponic nutrient solution, growth medium (substrate), and irrigation frequency on tomato plant photosynthetic response and found that the maximum leaf photosynthetic rate was increased by $15.4 \%$ and $14.1 \%$ when EC was increased from 2.5 to $4.0 \mathrm{dS} \cdot \mathrm{m}^{-1}$ for plants grown in nutrient film technique and rockwool systems, respectively. But a further increase of EC to $\mathbf{5 . 5}$ $\mathrm{dS} \cdot \mathrm{m}^{-1}$ resulted in a $10 \%$ lower maximum photosynthetic rate compared with that under $4.0 \mathrm{dS} \cdot \mathrm{m}^{-1} \mathrm{EC}$ when plants were grown in a rockwool system. Schwarz et al. (2002) found that an increase of EC from 1.25 $\mathrm{dS} \cdot \mathrm{m}^{-1}$ up to $8.75 \mathrm{dS} \cdot \mathrm{m}^{-1}$ did not reduce the leaf photosynthetic rate of tomato. In experiments reported by Xu et al. (1995) and Schwarz et al. (2002), the EC was enhanced by increasing the overall strength of nutrient solutions.

Romero-Aranda et al. (2001) showed that the leaf net photosynthetic rate of tomato plants was reduced proportionally as $\mathrm{NaCl}$ concentration increased in the nutrient solution $(0,35$, and $70 \mathrm{~mm} \mathrm{NaCl})$, and stated that the decrease might have resulted from the reduction in $g s$ and stomatal density. The nutrient solution examined in their experiment had 4.0 to 5.4 and 8.1 to 9.2 $\mathrm{dS} \cdot \mathrm{m}^{-1} \mathrm{EC}$ for 35 and $70 \mathrm{~mm} \mathrm{NaCl}$ treatments, and 1.8 to $2.0 \mathrm{dS} \cdot \mathrm{m}^{-1}$ for the control $(0 \mathrm{~mm} \mathrm{NaCl}$; R. RomeroAranda, personal communication). The decrease in net photosynthetic rate observed at EC of $4.0 \mathrm{dS} \cdot \mathrm{m}^{-1}$ or greater may be because of accumulated sodium in the plant tissue.

The plant photosynthetic and transpirational responses of commercially important cultivars to nutrient solutions of varied EC would provide critical information to facilitate optimization of tomato fruit quality, provide a basis for a reference study, and/or promote other long-term investigations in greenhouse production. The objective of this study was to evaluate the effects of EC of nutrient solution on tomato plant leaf photosynthetic response, transpiration rate, and stomatal leaf conductance and its interaction with cultivars and plant developmental stages.

\section{Materials and methods}

Plant material and growth CONDITIONs. Five greenhouse cultivars of tomatoes [Blitz (De Ruiter Seeds, Lakewood, CO), Mariachi (Rijk Zwaan Seeds Ltd., De Lier, The Netherlands), Rapsodie (Rogers Seeds, Boise, ID), Trust (De Ruiter Seeds), and Quest (De Ruiter Seeds)] were selected based on the trials conducted at the University of Arizona in previous years (Rorabaugh and Jensen, 2002). Seeds were sown into $4 \times 4$ $\mathrm{cm}$ rockwool cubes (Grodan BV, Roermond, The Netherlands) covered with a thin layer of vermiculite on 16 Sept. 2002 and were germinated under frequent water mist in the greenhouse. After the cotyledons were fully unfolded $(21 \mathrm{~d}$ after seeding), the seedlings were transplanted to $10 \times 10-\mathrm{cm}$ rockwool blocks (Grodan BV) and were subirrigated with full-strength modified Hoagland's nutrient solution (EC 2.3 $\mathrm{dS} \cdot \mathrm{m}^{-1}, \mathrm{pH}$ 6.0) once per day. When all plants had more than four fully expanded true leaves $(35 \mathrm{~d}$ after seeding), uniform seedlings were selected from each cultivar and subjected to one of three EC treatments $(2.3,4.8$, or $8.4 \mathrm{dS} \cdot \mathrm{m}^{-1}$; subirrigation once per day). The three EC levels were achieved by increasing the strength of the nutrient solution varied by proportionally increasing all ion concentrations relative to its full strength. The full-strength nutrient solution $\left(2.3 \mathrm{dS} \cdot \mathrm{m}^{-1}\right)$ contained the following elements: $142 \mathrm{mg} \cdot \mathrm{L}^{-1}$ nitrogen (all in nitrate form), $65 \mathrm{mg} \cdot \mathrm{L}^{-1}$ phosphorus, $374 \mathrm{mg} \cdot \mathrm{L}^{-1}$ potassium, $150 \mathrm{mg} \cdot \mathrm{L}^{-1}$ calcium, $50 \mathrm{mg} \cdot \mathrm{L}^{-1}$ magnesium, 2 $\mathrm{mg} \cdot \mathrm{L}^{-1}$ iron, $0.6 \mathrm{mg} \cdot \mathrm{L}^{-1}$ manganese, $0.3 \mathrm{mg} \cdot \mathrm{L}^{-1}$ zinc, $0.05 \mathrm{mg} \cdot \mathrm{L}^{-1}$ copper, $0.4 \mathrm{mg} \cdot \mathrm{L}^{-1}$ boron, and $0.05 \mathrm{mg} \cdot \mathrm{L}^{-1}$ molybdenum ( $M$. Jensen and $P$. Rorabaugh, unpublished data).

Forty-two days after seeding $(7 \mathrm{~d}$ after the start of EC treatments), plants were transplanted to l-gallon black plastic pots filled with a mixture of 1 vermiculite: 1 perlite: 1 peatmoss (by volume). Drip irrigation tubing was provided to each pot and nutrient solution with one of three EC was applied at 0800,1100 , and $1400 \mathrm{HR}$ daily (about $300-400 \mathrm{~mL}$ nutrient solution was supplied per irrigation event).

The experiment was conducted in a $24 \times 48$-ft compartment in a gutter-connected multispan greenhouse located at the University of Arizona Campus Agriculture Center in Tucson. The greenhouse was equipped with an evaporative cooling system with the exhaust fans located at the south end and the wet pads located at the north end of the greenhouse. The experimental plants were grown on benches located in the middle of the greenhouse compartment. Plants were grown on three 2.7 $\times 1.9-\mathrm{m}$ benches in the greenhouse, each with three replicates of EC treatments arranged according to the Latin square design. Five cultivars were randomly distributed within each replication of EC treatment. The total number of plants was 45 (three plants per cultivar per EC treatment).

Measurements. The EC, $\mathrm{pH}$, and volume of the inflow nutrient solution were recorded daily using a handheld $\mathrm{EC} / \mathrm{pH}$ probe (Hanna Instruments, Woonsocket, RI) and a volumetric cylinder. The $\mathrm{EC}, \mathrm{pH}$, and volume of the efflux nutrient solution were collected and recorded weekly. The temperature and relative 
humidity at the plant canopy were continuously recorded using wetand dry-bulb thermometers (gauge 18, type-T thermocouples) connected to a data logger (CR-10; Campbell Scientific, Logan, UT). The second fully open leaf below the shoot tip was selected from each plant for measurements of leaf conductance $\left(g_{l}\right)$, transpiration rate (TR), and net photosynthetic rate (NPR) in the vegetative and reproductive growth stages. The measurement for $g_{l}$ and TR during the vegetative growth stage was conducted $36 \mathrm{~d}$ after seeding, which was $\mathrm{l} \mathrm{d}$ after the start of EC treatments. The NPR in the plant vegetative and reproductive growth stages was measured 37 to $40 \mathrm{~d}$ after seeding (2-5 d after the start of EC treatments) and 68 to $75 \mathrm{~d}$ after seeding, during which period first small fruit settings were observed on the first truss. The $g_{l}$ and TR were measured using a portable photosynthesis measurement system (CIRAS2; PP Systems, Co., Amesbury, MA) set at a $1000 \mu \mathrm{mol} \cdot \mathrm{m}^{-2} \cdot \mathrm{s}^{-1}$ photosynthetic photon flux $(P P F), \quad 400$ $\mu \mathrm{mol} \cdot \mathrm{mol}^{-1}$ carbon dioxide $\left(\mathrm{CO}_{2}\right)$ concentration, and $200 \mathrm{~mL} \cdot \mathrm{min}^{-1}$ internal flow rate. Using the same system, NPR was measured under 6 $P P F$ levels $(0,250,500,1000$, and $\left.2000 \mu \mathrm{mol} \cdot \mathrm{m}^{-2} \cdot \mathrm{s}^{-1}\right)$ at $400 \mu \mathrm{mol}$. $\mathrm{mol}^{-1} \mathrm{CO}_{2}$ concentration under 200 $\mathrm{mL} \cdot \mathrm{min}^{-1}$ internal flow rate. The $g l$, TR, and NPR were measured during morning hours (no later than 1200 HR), before plants experienced midday high temperature and radiation. The NPR $\left(\mu \mathrm{mol} \cdot \mathrm{m}^{-2} \cdot \mathrm{s}^{-1}\right)$ at varied $P P F$ was fitted with a common photosynthetic model:

$N P R=k_{1} \times\left[1-\operatorname{Exp}\left(-\frac{k_{2}}{k_{1}} \times\left(P P F-k_{3}\right)\right)\right]$

where parameters $k_{1}, k_{2}$, and $k_{3}$ represent the maximum photosynthetic rate, initial slope, and light compensation point, respectively, and were estimated by nonlinear regression. Treatment and cultivar significances on these parameters were examined statistically using JMP software (version 5.1; SAS Institute, Cary, NC).

The experiment was conducted once. EC treatment and cultivar significances were analyzed by analysis of variance (ANOVA) followed by mean separations by Tukey's honestly significant difference (HSD) test $(\mathrm{n}=$ 3) using JMP software.

\section{Results and discussion}

GreENHOUSE TEMPERATURE AND RELATIVE HUMIDITy. Average day (0600-1800 HR) and night (1800$0600 \mathrm{HR}$ ) air temperatures inside the greenhouse during the experiment were $21.5 \pm 0.9^{\circ} \mathrm{C}$ and $13.3 \pm 0.8$ ${ }^{\circ} \mathrm{C}$, respectively. Average day and night relative humidity inside the greenhouse were $50.6 \% \pm 9.6 \%$ and $85.8 \% \pm 3.6 \%$, respectively.

EC OF NUTRIENT SOLUTION AND $\mathrm{pH}$. The average EC and $\mathrm{pH}$ of the inflow solution during the experiment was $2.3 \pm 0.4 \mathrm{dS} \cdot \mathrm{m}^{-1}$ and $6.3 \pm$ 0.2 in the low EC treatment, $4.8 \pm$ $0.9 \mathrm{dS} \cdot \mathrm{m}^{-1}$ and $6.3 \pm 0.3$ in the moderate EC treatment, and $8.4 \pm$ $0.7 \mathrm{dS} \cdot \mathrm{m}^{-1}$ and $6.2 \pm 0.3$ in the high EC treatment. The average EC and $\mathrm{pH}$ of the efflux solution during the experiment was $5.9 \pm 1.3 \mathrm{dS} \cdot \mathrm{m}^{-1}$ and $7.1 \pm 0.5$ in the low EC treatment, $8.7 \pm 2.1 \mathrm{dS} \cdot \mathrm{m}^{-1}$ and $7.6 \pm 0.5$ in the moderate EC treatment, and $14.3 \pm$ $2.5 \mathrm{dS} \cdot \mathrm{m}^{-1}$ and $7.4 \pm 0.6$ in the high EC treatment. The average efflux percentage over the inflow nutrient solution was $35 \%$ for the low EC treatment, $31 \%$ for the moderate EC treatment, and $37 \%$ for high EC treatment, all of which are within the conventional range recommended in commercial hydroponic tomato production. The relatively high EC of the efflux solution was because of the infrequent irrigation (three times per day), despite the conventional efflux percentage. Although we could not measure the EC in the root zone directly in this experiment, the high efflux EC means that there were relatively large diurnal fluctuations in EC between successive irrigation events.

LEAF CONDUCTANCE AND TRANSPIRATION. The TR and $g_{l}$ as affected by EC and cultivar are shown in Table 1 . When measured $1 \mathrm{~d}$ after start of the EC treatments during the vegetative growth stage, the high EC treatment reduced TR and $g_{l}$ by $29 \%$ and $28 \%$, respectively, compared with the low EC control, suggesting that the reduction in TR was associated with the decreased $g_{l}$. However, there was no significant difference in TR and $g_{l}$ between the moderate EC treatment and the low or high EC treatment. A similar correlation between TR and $g_{l}$ under varied EC levels was reported by RomeroAranda et al. (2001).

When measured after first fruit set (the reproductive growth stage),

Table 1. Transpiration rate (TR) and leaf conductance $\left(g_{l}\right)$ of tomato plants as affected by electrical conductivity (EC) of the nutrient solution and cultivar, measured $1 \mathrm{~d}$ after start of EC treatment during the vegetative growth stage and the reproductive stage (after first fruit set).

\begin{tabular}{|c|c|c|c|c|}
\hline \multirow[b]{2}{*}{ Factor } & \multicolumn{2}{|c|}{$\begin{array}{l}\text { Vegetative growth } \\
\text { stage }\end{array}$} & \multicolumn{2}{|c|}{$\begin{array}{l}\text { Reproductive growth } \\
\text { stage }\end{array}$} \\
\hline & $\begin{array}{c}\text { TR } \\
\left(\mathrm{mmol} \cdot \mathrm{m}^{-2} \cdot \mathrm{s}^{-1}\right)\end{array}$ & $\begin{array}{c}g_{l} \\
\left(\mathrm{mmol} \cdot \mathrm{m}^{-2} \cdot \mathrm{s}^{-1}\right) \\
\end{array}$ & $\begin{array}{c}\text { TR } \\
\left(\mathrm{mmol} \cdot \mathrm{m}^{-2} \cdot \mathrm{s}^{-1}\right)\end{array}$ & $\begin{array}{c}g_{l} \\
\left(\mathrm{mmol} \cdot \mathrm{m}^{-2} \cdot \mathrm{s}^{-1}\right)\end{array}$ \\
\hline \multicolumn{5}{|l|}{$\mathrm{EC}^{\mathrm{y}}$} \\
\hline Low & $4.0 \mathrm{a}^{\mathrm{z}}$ & $188.9 \mathrm{a}$ & 6.3 & $445.9 \mathrm{a}$ \\
\hline Moderate & $3.6 \mathrm{ab}$ & $183.1 \mathrm{ab}$ & 6.4 & $438.0 \mathrm{ab}$ \\
\hline High & $2.8 \mathrm{~b}$ & $135.6 b$ & 5.8 & $380.6 b$ \\
\hline \multicolumn{5}{|l|}{ Cultivar } \\
\hline Blitz & $3.9 \mathrm{a}$ & $204.9 a$ & 6.1 & $411.7 \mathrm{ab}$ \\
\hline Mariachi & $4.6 \mathrm{a}$ & $241.4 \mathrm{a}$ & 5.8 & $380.2 b$ \\
\hline Rapsodie & $3.7 \mathrm{ab}$ & $183.2 \mathrm{ab}$ & 6.6 & $460.6 a$ \\
\hline Trust & $2.3 \mathrm{c}$ & $108.6 \mathrm{c}$ & 6.4 & $473.0 \mathrm{a}$ \\
\hline Quest & $2.8 b$ & $135.0 \mathrm{bc}$ & 6.0 & $391.1 \mathrm{ab}$ \\
\hline \multicolumn{5}{|c|}{ ANOVA $(P=0.05)$} \\
\hline $\mathrm{EC}$ & * & * & NS & * \\
\hline Cultivar & * & * & NS & * \\
\hline Cultivar $\times$ EC & NS & NS & NS & NS \\
\hline
\end{tabular}

${ }^{\mathrm{z}}$ Means followed by the same letters within the column are not significantly different according to an analysis of variance-protected Tukey's honestly significant difference test at $P=0.05$

${ }^{\mathrm{y}}$ Low $=2.3 / 5.9 \mathrm{dS} \cdot \mathrm{m}^{-1}$, moderate $=4.8 / 8.7 \mathrm{dS} \cdot \mathrm{m}^{-1}$, and high $=8.4 / 14.3 \mathrm{dS} \cdot \mathrm{m}^{-1}$ for inflow $/$ efflux solution $\left(1 \mathrm{dS} \cdot \mathrm{m}^{-1}=1 \mathrm{mmho} / \mathrm{cm}\right)$.

${ }^{\text {Ns Nonsignificant. }}$ 
the EC treatments did not significantly affect the TR. For $g_{l}$ in the reproductive stage, the high EC treatment significantly reduced $g_{l}$ by $15 \%$ compared with low EC. However, there was no difference in $g_{l}$ between the moderate EC treatment and the low or high EC treatment. No significant difference in TR and a smaller reduction in $g_{l}$ by high EC treatment in the reproductive growth stage than in the vegetative growth stage might be because of the plant's osmotic adjustment after prolonged exposure to high EC. Osmotic adjustment in a plant is an important adaptation to water stress by decreasing the leaf water potential to compensate the lowering of water potential in the nutrient solution (Guerrier, 1996; Shannon et al., 1987). The ratios of TR and $g_{l}$ measured in the reproductive growth stage were 0.014 to 0.015 , being significantly smaller than those measured in the vegetative growth stage (0.019-0.021). If the greater TR observed in the reproductive than the vegetative growth stage was caused by the increased $g_{l}$, the $\mathrm{TR} / g_{l}$ ratio, representing a driving force of transpiration rate, should have been the same. Therefore, the difference in $\mathrm{TR} / g_{l}$ may suggest that there were physiological changes between two stages, such as acclimation to salt stress. Similarly, acclimation of hydroponic tomato plants to salt stress and water deficit was observed by Xu et al. (1997).

'Blitz', 'Mariachi', and 'Rapsodie' had similar TR and $g_{l}$, whereas 'Trust' exhibited lower TR than 'Blitz', 'Mariachi', 'Rapsodie', and 'Quest', and lower $g_{l}$ than 'Blitz', 'Mariachi', and 'Rapsodie' when measured $\mathrm{l} d$ after the start of EC treatment during the vegetative growth stage (Table 1). 'Quest' had a TR similar to 'Rapsodie', and a $g_{l}$ similar to 'Rapsodie' or 'Trust'. The relatively low TR and $g_{l}$ in 'Trust' may be because 'Trust' is a cultivar well adapted to northern climates with lower radiation and air temperature compared with the other cultivars. In fact, 'Trust' is widely cultivated in Northern European countries such as in Denmark and is known to be sensitive to a high-light environment (De Ruiter Seeds, unpublished data). 'Blitz' performs well under high-light and high-temperature conditions, and the plant grows more vegetatively than reproductively (De Ruiter Seeds, unpublished data). 'Mariachi' and 'Rapsodie' reportedly had a better adaptation to heat than 'Quest' according to trials conducted for 2 years in Arizona (Rorabaugh and Jensen, 2002). During the reproductive growth stage, all cultivars had greater TR than those measured $\mathrm{l} d$ after EC treatment during vegetative growth stage, but there was no difference in TR among cultivars. The $g_{l}$ for 'Rapsodie' and 'Trust' were similar to 'Blitz' and 'Quest' or greater than 'Mariachi' during the reproductive growth stage. The overall difference in $g_{l}$ between treatments was smaller during the reproductive growth stage
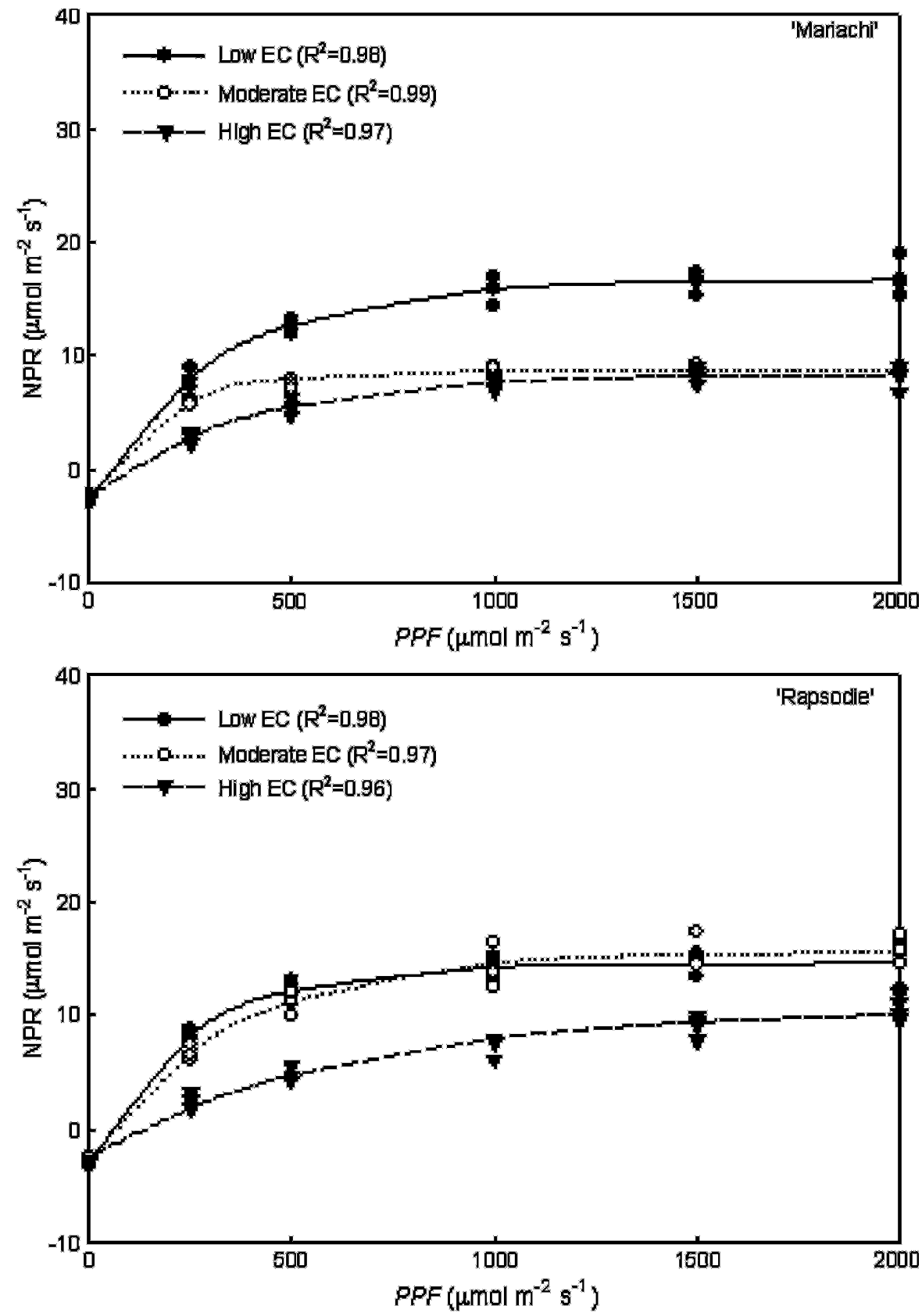

Fig. 1. Leaf photosynthetic light response curve of 'Mariachi' and 'Rapsodie' tomato plants in the vegetative stage as affected by $\mathrm{EC}$ treatments [low EC $=2.3$ / $5.9 \mathrm{dS} \cdot \mathrm{m}^{-1}$, moderate $\mathrm{EC}=4.8 / 8.7 \mathrm{dS} \cdot \mathrm{m}^{-1}$, and high $\mathrm{EC}=8.4 / 14.3 \mathrm{dS} \cdot \mathrm{m}^{-1}$ for inflow/efflux solution, respectively $\left.\left(1 \mathrm{dS} \cdot \mathrm{m}^{-1}=1 \mathrm{mmho} / \mathrm{cm}\right)\right]$. The data were obtained during plant vegetative stage, and were fitted with the model, $N P R=k_{1}\{1$ $\left.-\exp \left[-k_{2}\left(P P F-k_{3}\right) / k_{1}\right]\right\}$, where $N P R$ is net photosynthetic rate $\left(\mu \mathrm{mol} \cdot \mathrm{m}^{-2} \cdot \mathrm{s}^{-1}\right)$, $P P F$ is $P P F\left(\mu \mathrm{mol} \cdot \mathrm{m}^{-2} \cdot \mathrm{s}^{-1}\right)$, and $\mathrm{k}_{1}, \mathrm{k}_{2}$, and $\mathrm{k}_{3}$ represent the maximum photosynthetic rate, initial slope, and light compensation point, respectively. 
than that during the vegetative growth stage.

Photosythetic Light RESPONSE. The photosynthetic light response curves during the vegetative growth stage for 'Mariachi' and 'Rapsodie' are shown in Fig. 1. The photosynthetic light response curves obtained for all five cultivars during the reproductive growth stage are shown in Fig. 2. The parameters of photosynthetic response curves, maximum photosynthetic rate $\left(k_{1}\right)$, initial slope $\left(k_{2}\right)$, and light compensation point $\left(k_{3}\right)$, as affected by cultivar and EC, are shown in Tables 2 and 3 . During the vegetative growth stage, the high EC and moderate EC treatments reduced the maximum photosynthetic rate for 'Mariachi' by an average of $48.8 \%$ compared with the low EC treatment. For 'Rapsodie', the moderate EC treatment had the greatest maximum photosynthetic rate out of the three EC treatments. For 'Mariachi' and 'Rapsodie', initial slope decreased and light compensation point increased with increasing EC. The lower initial slope observed in the higher EC treatments indicates a lower efficiency of photosynthesis under low light conditions, and the greater light compensation point in the higher EC treatments indicates a greater respiration rate than those in the lower EC treatments. We observed that the plant vegetative growth (stem length and leaf size) was significantly reduced in moderate and high EC treatments regardless of cultivar (data not shown), which may be attributed to lower photosynthetic efficiency and greater respiration under the EC treatments.

During the reproductive growth stage, there was no significant difference in maximum photosynthetic rate between low and moderate EC treatments for all cultivars except 'Rapsodie'. 'Rapsodie' had a $26 \%$ greater maximum photosynthetic rate for the moderate EC than for low EC treatment. The maximum photosynthetic rate in the high EC treatment was significantly lower than that in the low EC treatment by $38 \%$ and $23 \%$ for 'Blitz' and 'Mariachi', respectively, whereas no significant difference was observed in the maximum photosynthetic rate between high and low EC treatments for 'Rapsodie', 'Trust', and 'Quest'. Neither EC treatment nor cultivar affected the
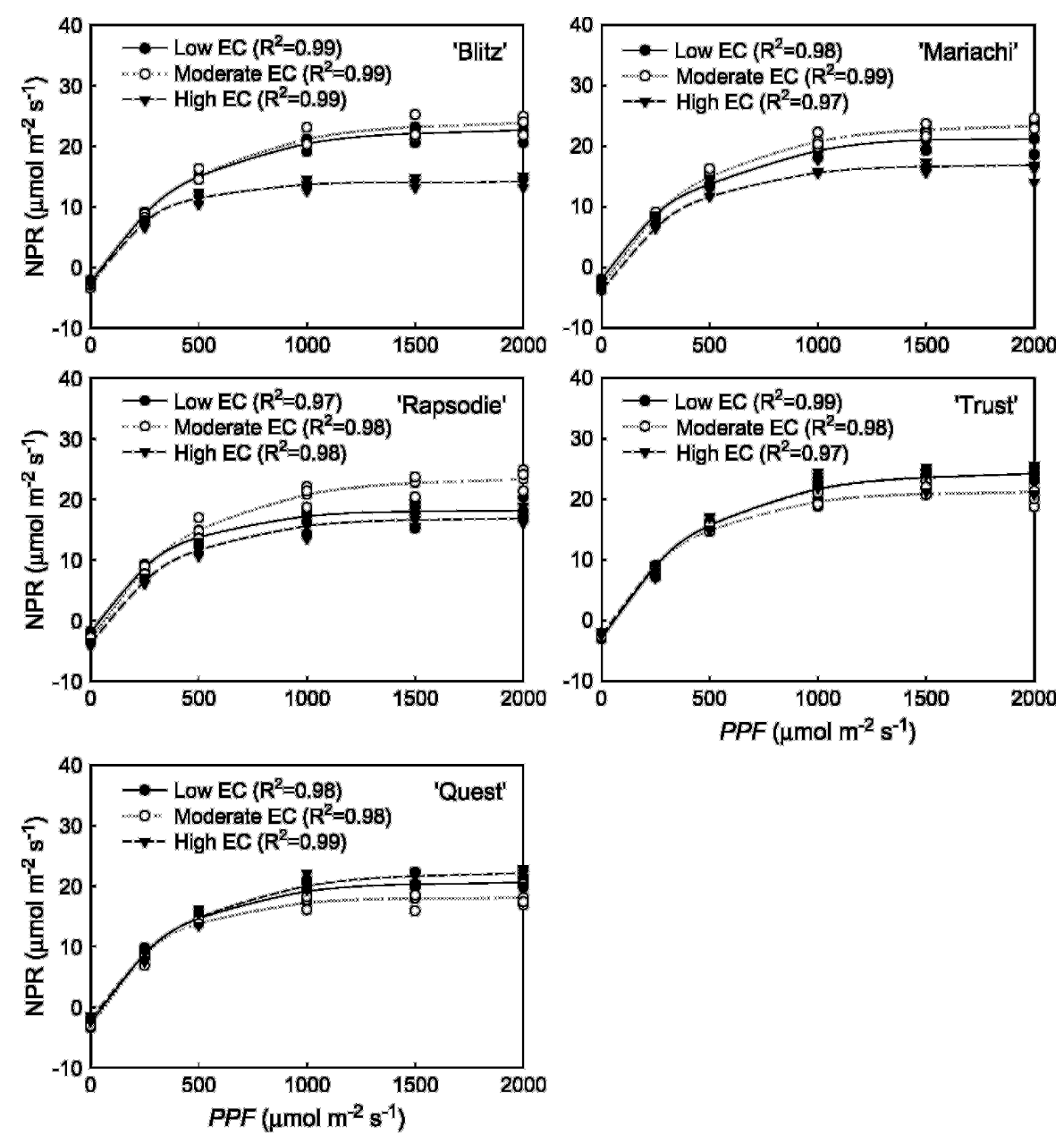

Fig. 2. Leaf photosynthetic light response curve of 'Rapsodie', 'Blitz', 'Mariachi', 'Trust', and 'Quest' in the reproductive stage as affected by EC treatments [low EC $=2.3 / 5.9 \mathrm{dS} \cdot \mathrm{m}^{-1}$, moderate $\mathrm{EC}=4.8 / 8.7 \mathrm{dS} \cdot \mathrm{m}^{-1}$, and high $\mathrm{EC}=8.4 / 14.3 \mathrm{dS} \cdot \mathrm{m}^{-1}$ for inflow/efflux solution, respectively $\left.\left(1 \mathrm{dS} \cdot \mathrm{m}^{-1}=1 \mathrm{mmho} / \mathrm{cm}\right)\right]$. The data were obtained during plant reproductive stage and were fitted with the model, NPR $=k_{1}\left\{1-\exp \left[-k_{2}\left(P P F-k_{3}\right) / k_{1}\right]\right\}$, where $N P R$ is net photosynthetic rate $\left(\mu \mathrm{mol} \cdot \mathrm{m}^{-2} \cdot \mathrm{s}^{-1}\right), P P F$ is $P P F\left(\mu \mathrm{mol} \cdot \mathrm{m}^{-2} \cdot \mathrm{s}^{-1}\right)$, and $\mathrm{k}_{1}, \mathrm{k}_{2}$, and $\mathrm{k}_{3}$ represent the maximum photosynthetic rate, initial slope, and light compensation point, respectively.

initial slope of the photosynthetic light response curve. The EC treatment did not significantly affect the light compensation point for all cultivars except 'Rapsodie', where high EC treatment caused a greater light compensation point than low or moderate EC treatment.

The rather unique response of 'Rapsodie' photosynthetic parameters to EC treatment compared with other cultivars may be attributed to its genotype, as 'Rapsodie' is reportedly suitable for cultivation under relatively mild climate and greater radiation at latitude of $36^{\circ}$ or less (Roger Seeds, unpublished data). It is also known that 'Rapsodie' is relatively tolerant to water stress (P. Costa, unpublished data). Noticeably, 'Rapsodie' showed the highest NPR under moderate EC treatment compared with low and high EC treatments, regardless of the plant growth stage, suggesting that the optimum EC levels for growth and resulting yields for 'Rapsodie' may be close to the moderate EC that we examined.

Romero-Aranda et al. (2001) observed cultivar specific responses in leaf gas exchange characteristics in response to different $\mathrm{NaCl}$ concentrations. For 'Daniela' tomato plants, an increase of $\mathrm{NaCl}$ from $0 \mathrm{~mm}$ (EC $1.8-2.0 \mathrm{dS} \cdot \mathrm{m}^{-1}$ ) to $35 \mathrm{~mm}$ (EC $4.0-$ $5.4 \mathrm{dS} \cdot \mathrm{m}^{-1}$ ) or $70 \mathrm{~mm}$ (EC $8.1-9.2$ $\mathrm{d} S \cdot \mathrm{m}^{-1}$ ) reduced the leaf $g_{\mathrm{s}}$ by $40 \%$ or $68 \%$, respectively. For 'Moneymaker', 
high $\mathrm{NaCl}$ treatments of 35 and 70 mu reduced the leaf $g_{S}$ by $52 \% \mathrm{com}^{-}$ pared with the control at $0 \mathrm{~mm}$ of $\mathrm{NaCl}$ in the nutrient solution. The leaf

transpiration rate decreased by about $27 \%$ and $60 \%$ for 'Daniela' and by $52 \%$ and $50 \%$ for 'Moneymaker' under 35 and $70 \mathrm{~mm} \mathrm{NaCl}$ treatments,

Table 2. Effects of electrical conductivity (EC) of the nutrient solution and cultivar (Mariachi and Rapsodie) on maximum photosynthetic rate, initial slope, and light compensation point of tomato plants during the vegetative growth stage.

\begin{tabular}{|c|c|c|c|}
\hline Factor $^{\mathrm{y}}$ & $\begin{array}{c}\text { Maximum } \\
\text { photosynthetic } \\
\operatorname{rate}^{\mathrm{x}}\left(\mu \mathrm{mol} \cdot \mathrm{m}^{-2} \cdot \mathrm{s}^{-1}\right)\end{array}$ & $\begin{array}{l}\text { Initial } \\
\text { slope }^{x}\end{array}$ & $\begin{array}{c}\text { Light } \\
\text { compensation point } \\
\left(\mu \mathrm{mol} \cdot \mathrm{m}^{-2} \cdot \mathrm{s}^{-1}\right) \\
\end{array}$ \\
\hline \multicolumn{4}{|l|}{ ‘Mariachi' } \\
\hline Low & $16.7 \mathrm{a}$ & $0.052 \mathrm{~b}$ & $45.6 \mathrm{c}$ \\
\hline Moderate & $8.7 \mathrm{e}$ & $0.046 \mathrm{bc}$ & $45.2 \mathrm{c}$ \\
\hline High & $8.4 \mathrm{e}$ & $0.022 \mathrm{~d}$ & $97.9 \mathrm{a}$ \\
\hline \multicolumn{4}{|l|}{ 'Rapsodie' } \\
\hline Low & $14.6 \mathrm{c}$ & $0.057 \mathrm{a}$ & $46.1 \mathrm{c}$ \\
\hline Moderate & $15.7 \mathrm{~b}$ & $0.044 \mathrm{c}$ & $57.0 \mathrm{~b}$ \\
\hline High & $10.7 \mathrm{~d}$ & $0.017 \mathrm{e}$ & $128.7 \mathrm{a}$ \\
\hline
\end{tabular}

${ }^{\mathrm{z}}$ Maximum photosynthetic rate, initial slope, and light compensation point were obtained from a nonlinear regression analysis using a model, $N P R=k_{1}\left\{1-\exp \left[-k_{2}\left(P P F-k_{3}\right) / k_{1}\right]\right\}$, where $N P R$ is net photosynthetic rate $\left(\mu \mathrm{mol} \cdot \mathrm{m}^{-2} \cdot \mathrm{s}^{-1}\right)$ and $k_{1}, k_{2}$, and $k_{3}$ are the maximum photosynthetic rate, initial slope, and light compensation point, respectively.

${ }^{y}$ EC levels: low $=2.3 / 5.9 \mathrm{dS} \cdot \mathrm{m}^{-1}$, moderate $=4.8 / 8.7 \mathrm{dS} \cdot \mathrm{m}^{-1}$, and high $=8.4 / 14.3 \mathrm{dS} \cdot \mathrm{m}^{-1}$ for inflow $/$ efflux solution, respectively $\left(1 \mathrm{dS} \cdot \mathrm{m}^{-1}=1 \mathrm{mmho} / \mathrm{cm}\right)$.

${ }^{\mathrm{x}}$ Means followed by the same letters within the column are not significantly different according to an analysis of variance-protected Tukey's honestly significant difference test at $P=0.05$.

Table 3. Effects of electrical conductivity (EC) of nutrient solution and cultivar (Blitz, Mariachi, Rapsodie, Trust, and Quest) on maximum photosynthetic rate, initial slope, and light compensation point of tomato plants during the reproductive growth stage.

\begin{tabular}{|c|c|c|c|}
\hline Factor $^{\mathrm{y}}$ & $\begin{array}{c}\text { Maximum } \\
\text { photosynthetic rate } \\
\left(\mu \mathrm{mol} \cdot \mathrm{m}^{-2} \cdot \mathrm{s}^{-1}\right)\end{array}$ & $\begin{array}{l}\text { Initial } \\
\text { slope }^{\mathrm{x}}\end{array}$ & $\begin{array}{c}\text { Light } \\
\underset{\left(\mu \mathrm{mol} \cdot \mathrm{m}^{-2} \cdot \mathrm{s}^{-1}\right)}{\text { compensation point }} \\
\end{array}$ \\
\hline \multicolumn{4}{|l|}{ 'Blitz' } \\
\hline Low & $22.9 a$ & 0.053 & $44.6 \mathrm{bc}$ \\
\hline Moderate & $24.0 \mathrm{a}$ & 0.054 & $55.5 \mathrm{ab}$ \\
\hline High & $14.1 \mathrm{f}$ & 0.052 & $46.5 b c$ \\
\hline \multicolumn{4}{|l|}{ 'Mariachi' } \\
\hline Low & $21.4 \mathrm{abc}$ & 0.053 & $50.6 b c$ \\
\hline Moderate & $23.6 \mathrm{a}$ & 0.054 & $56.7 \mathrm{ab}$ \\
\hline High & $16.4 \mathrm{ef}$ & 0.061 & $50.0 \mathrm{bc}$ \\
\hline \multicolumn{4}{|l|}{ 'Rapsodie' } \\
\hline Low & 18.5 bcde & 0.054 & $35.5 \mathrm{c}$ \\
\hline Moderate & $23.3 \mathrm{a}$ & 0.054 & $53.1 b c$ \\
\hline High & $16.8 \mathrm{def}$ & 0.046 & $72.8 \mathrm{a}$ \\
\hline \multicolumn{4}{|l|}{ 'Trust' } \\
\hline Low & $24.5 \mathrm{a}$ & 0.056 & $49.5 \mathrm{bc}$ \\
\hline Moderate & $21.4 \mathrm{abc}$ & 0.056 & $47.6 \mathrm{bc}$ \\
\hline High & $24.7 \mathrm{a}$ & 0.055 & $41.6 b c$ \\
\hline \multicolumn{4}{|l|}{ 'Quest' } \\
\hline Low & $20.7 \mathrm{abcd}$ & 0.056 & $44.4 \mathrm{bc}$ \\
\hline Moderate & $18.2 \mathrm{cdef}$ & 0.058 & $51.8 b c$ \\
\hline High & $22.4 \mathrm{ab}$ & 0.052 & $39.0 \mathrm{bc}$ \\
\hline
\end{tabular}

${ }^{\mathrm{z}}$ Maximum photosynthetic rate, initial slope, and light compensation point were obtained from a nonlinear regression analysis using a model, $N P R=k_{1}\left\{1-\exp \left[-k_{2}\left(P P F-k_{3}\right) / k_{1}\right]\right\}$, where NPR is net photosynthetic rate $\left(\mu \mathrm{mol} \cdot \mathrm{m}^{-2} \cdot \mathrm{s}^{-1}\right)$ and $k_{1}, k_{2}$, and $k_{3}$ are the maximum photosynthetic rate, initial slope, and light compensation point, respectively.

${ }^{y}$ EC levels: low $=2.3 / 5.9 \mathrm{dS} \cdot \mathrm{m}^{-1}$, moderate $=4.8 / 8.7 \mathrm{dS} \cdot \mathrm{m}^{-1}$, and high $=8.4 / 14.3 \mathrm{dS} \cdot \mathrm{m}^{-1}$ for inflow $/$ efflux solution, respectively $\left(1 \mathrm{dS} \cdot \mathrm{m}^{-1}=1 \mathrm{mmho} / \mathrm{cm}\right)$.

${ }^{x}$ Means followed by the same letters within the column are not significantly different according to an analysis of variance-protected Tukey's honestly significant difference test at $P=0.05$. respectively, compared with the control. In our study, the effect of moderate to high EC $\left(4.8-8.4 \mathrm{dS} \cdot \mathrm{m}^{-1}\right.$ for inflow solution) of nutrient solution on photosynthetic characteristics was also cultivar specific.

Xu et al. (1995) found that EC at $4.0 \mathrm{dS} \cdot \mathrm{m}^{-1}$ could increase the tomato leaf NPR compared with the control of $2.0 \mathrm{dS} \cdot \mathrm{m}^{-1}$ in nutrient film technique and rockwool systems. Schwarz et al. (2002) found that an increase of EC from 1.25 to $8.75 \mathrm{dS} \cdot \mathrm{m}^{-1}$ did not reduce the leaf net photosynthetic rate of tomato plants. These differences in plant responses as affected by EC among the previously reported experiments might be also attributed to plant growth environments, such as light levels used in the measurements. In Xu et al. (1995), the leaf net photosynthetic rate was measured under $1000 \mu \mathrm{mol} \cdot \mathrm{m}^{-2} \cdot \mathrm{s}^{-1} P P F$, whereas it was measured under 400 and 625 $\mu \mathrm{mol} \cdot \mathrm{m}^{-2} \cdot \mathrm{s}^{-1}$ PPF of two controlled environment chambers in Schwarz et al. (2002). Therefore, the lower PPF in Schwarz et al. (2002) might have mitigated the effect of high EC on the photosynthesis and resulted in sustained leaf photosynthetic rates at higher EC than those in Xu et al. (1995). Our results also showed that differences between the EC treatments were smaller under $P P F$ lower than $500 \mu \mathrm{mol} \cdot \mathrm{m}^{-2} \cdot \mathrm{s}^{-1}$ than that under PPF greater than 1000 $\mu \mathrm{mol} \cdot \mathrm{m}^{-2} \cdot \mathrm{s}^{-1}$, especially in the reproductive stage.

There were somewhat different responses of photosynthetic characteristics to moderate or high EC between vegetative and reproductive growth stages for 'Mariachi' and 'Rapsodie' in the present experiment. The maximum photosynthetic rate was relatively greater in the reproductive growth stage than in the vegetative growth stage within the same EC treatment. The initial slope of the photosynthetic response curve decreased with increasing EC for the vegetative growth stage, whereas there was no significant difference between EC treatments for the reproductive growth stage. These changes observed between two stages may be caused by the plant acclimation to the increased EC levels, as similarly observed for TR and $g_{l}$ (Table 1). Another possible reason for greater maximum photosynthetic rate in the reproductive stage than those in the 
vegetative stage is the increased sink strength of plant in the reproductive growth stage than the vegetative growth stage, a phenomenon associated with a sink-source relationship (Ho, 1988). The reduction in sink activity caused an increase in sucrose in source leaves and led to a decrease in photosynthetic rate by feedback inhibition (Stitt, 1991).

In the present experiment, we could not obtain the final yield data because of technical problems. Instead, we conducted a separate experiment with four cultivars (Blitz, Mariachi, Quest, and Rapsodie) of tomato plants grown hydroponically and reported that a moderate EC (4.5 $\left.\mathrm{dS} \cdot \mathrm{m}^{-1}\right)$ increased TSS and lycopene concentration of fruit by $12 \%$ to $23 \%$ and $34 \%$ to $85 \%$, respectively, but did not significantly affected the cumulative yield of 7 weeks (Wu et al., 2004), which agrees with what indicated from the present study result that leaf gas exchange rates were at the similar level over low to moderate EC (2.3$4.8 \mathrm{dS} \cdot \mathrm{m}^{-1}$ ) during the reproductive growth stage, except 'Rapsodie'. Nevertheless, we consider that leaf gas exchange rates provide hydroponic greenhouse growers with reference information useful to select EC levels that can increase the fruit quality while minimizing the potential yield reduction.

\section{Conclusions}

The photosynthetic and transpirational responses of tomato plants were affected by cultivar, EC of nutrient solution, and plant growth stages. During the reproductive growth stage, photosynthesis and transpiration were less affected by higher EC in the nutrient solution than in the vegetative stage. The relatively sensitive response to $\mathrm{EC}$ of leaf gas exchange rates and its related parameters observed during the vegetative growth stage suggests that the application timing of high EC should not be too early in the vegetative stage, as it could possibility stunt the overall plant growth by reducing photosynthetic and transpiration rates. For all cultivars tested in the present experiment, leaf gas exchange rates showed that a moderate EC (4.8 $\mathrm{dS} \cdot \mathrm{m}^{-1}$ ) of influx nutrient solution during the reproductive growth stage provided tomato plants with a moderate water stress that could improve the fruit quality while sustaining yields. This hypothesis on fruit quality and yields was confirmed in our separate report (Wu et al., 2004).

\section{Literature cited}

Adams, P. 1991. Effects of increasing the salinity of the nutrients solution with major nutrients or sodium chloride on the yield, quality and composition of tomato grown in rockwool. J. Hort. Sci. 66:201-207.

Adams, P. and L.C. Ho. 1989. Effect of constant and fluctuating salinity on the yield, quality and calcium status of tomatoes. J. Hort. Sci. 64:725-732.

Cook, R. and L. Calvin. 2005. Greenhouse tomatoes change the dynamics of the North American Fresh Tomato Industry. USDA Econ. Res. Rpt. No. 2. 22 Mar. 2006. <http://www.ers.usda.gov/ publications/err2/>.

Cornish, P.S. 1992. Use of high electrical conductivity of nutrients solution to improve the quality of salad tomatoes grown in hydroponic culture. J. Expt. Agr. 32:513-520.

Dorais, M., A. Papadopoulos, and A. Gosselin. 2001. Influence of electric conductivity management on greenhouse tomato yield and fruit quality. Agronomie 21:367-383.

Greenway, H. and R. Munns. 1980. Mechanisms of salt tolerance in nonhalophytes. Annu. Rev. Plant Physiol. 31:149-190.

Guerrier, G. 1996. Fluxes of $\mathrm{Na}^{+}, \mathrm{K}^{+}$and $\mathrm{Cl}^{-}$, and osmotic adjustment in Lycopersicon pimpinellifolium and L. esculentum during short-and long-term exposures to NaCl. Physiol. Plant. 97:583-591.

Ho, L.C. 1988. Metabolism and compartmentation of imported sugars in sink organs in relation to sink strength. Annu. Rev. Plant Physiol. Plant Mol. Biol. 39:355-378.

Jones, J. 1999. Tomato plant culture. CRC Press, Boca Raton, FL.

Leonardi, C., M. Martorana, F. Giuffrida, V. Fogliano, and R. Pernice. 2004. Tomato fruit quality in relation to the content of sodium chloride in the nutrient solution. Acta Hort. 659:769-774.

Lin, W.C. and A.D.M. Glass. 1999. The effects of $\mathrm{NaCl}$ addition and macronutrient concentration on fruit quality and flavor volatiles of greenhouse tomatoes. Acta Hort. 481:487-491.

Mitchell, J.P., C. Shennan, and S.R. Grattan. 1991. Developmental changes in tomato fruit composition in response to water deficit and salinity. Physiol. Plant. 83:177-185.

Rick, C.M. 1995. Tomato, Lycopersicon esculentum (Solanaceae), p. 452-457. In: J. Smartt and N.W. Simmonds (eds.). Evolution of crop plants. 2nd ed. Longman, London.

Romero-Aranda, R., T. Soria, and J. Cuartero. 2001. Tomato plant-water uptake and plant-water relationships under saline growth conditions. Plant Sci. 160:265-272.

Rorabaugh, P.A. and M.H. Jensen. 2002. A trial to test heat tolerant tomato varieties for use in desert climates. Trial 2. 20012002. 10 Oct. 2006. <http://ag.arizona. edu / CEAC/research / a rchive / HEAT\%20TOLERANT\%20TOMATO\% 20VAR\%20paper\%202001\%202002.doc>.

Schwarz, D., H.P. Klaring, M.W. Van Iersel, and I.T. gram. 2002. Growth and photosynthetic response of tomato to nutrient solution concentration at two light levels. J. Amer. Soc. Hort. Sci. 127: 984-990.

Shannon, M.C., J.W. Gronwald, and M. Tal. 1987. Effects of salinity on growth and accumulation of organic and inorganic ions in cultivated and wild tomato species. J. Amer. Soc. Hort. Sci. 112:416-423.

Steta, M. 2004. Mexico as the new major player in the vegetable greenhouse industry. Acta Hort. 259:31-36.

Stevens, M.A., A.A. Kader, and M. Albright-Houlton. 1977. Intercultivar variation in composition of locular and pericarp portions of fresh market tomatoes. J. Amer. Soc. Hort. Sci. 102:689-692.

Stitt, M. 1991. Rising $\mathrm{CO}_{2}$ levels and their potential significance for carbon flow in photosynthetic cells. Plant Cell Environ. 14:741-762.

Wu, M., J.S. Buck, and C. Kubota. 2004. Effects of nutrient solution EC, plant microclimate and cultivars on fruit quality and yield of hydroponic tomatoes ( Lycopersicon esculentum). Acta Hort. 659:541-547.

$\mathrm{Xu}$, H.L., L. Gauthier, and A. Gosselin. 1995. Effects of fertigation management on growth and photosynthesis of tomato plant grown in peat, rockwool and NFT. Scientia Hort. 63:11-20.

$\mathrm{Xu}$, H.L., L. Gauthier, and A. Gosselin. 1997. Greenhouse tomato photosynthetic acclimation to water deficit and response to salt accumulation in the substrate. J. Jpn. Soc. Hort. Sci. 65:777-784.

Young, T.E., J.A. Juvik, and J.G. Sullivan. 1993. Accumulation of the components of total solids in ripening fruits of tomato. J. Amer. Soc. Hort. Sci. 118:286-292. 